\title{
Artigos
}

Natália Salomé de Souza

Universidade Federal de Mato Grosso, Cuiabá, MT, Brasil

Vinícius Carvalho Pereira

Universidade Federal de Mato Grosso, Cuiabá, MT, Brasil

\section{A escrita da mulher/a escrita feminina na poesia de Maria Teresa Horta}

Resumo: Na busca de uma escrita que falasse do corpo feminino pela própria mulher, encontramos a lírica de Maria Teresa Horta. Em seus poemas, a eu-lírica dá voz a um corpo feminino, de forma a desamarrá-lo do jugo patriarcal. Há, portanto, uma voz e escrita femininas que partem de uma imanência corporal manifestada, a princípio, na fala - no conceito de falar (como) mulher, de Luce Irigaray - para então se concretizar na escrita - escrita feminina de Hélène Cixous. O percurso teórico aqui empreendido para análise literária dessa escrita é embasado no feminismo da diferença. Para Hélène Cixous e Luce Irigaray, teóricas do feminismo da diferença, com o empoderamento de sua linguagem, a mulher subverte o falogocentrismo, empoderando-se de si e fomentando uma nova possibilidade de articulação da mulher na arte e na cultura. Sob tal perspectiva, a poesia de Horta se torna libertária, na medida em que diz de um corpo que se escreve.

Palovras-chave: Escrita feminina; diferença sexual; Maria Teresa Horta

Tem uma língua que eu falo ou que fala para/por mim em todas as línguas. E essa língua, eu sei, eu não preciso acessá-la, ela surge de mim, ela me inunda, ela é o leite do amor, o mel do meu inconsciente. A linguagem que as mulheres falam quando não tem ninguém por perto para corrigi-las.

Hélène Cixous

\section{(c) (1)}

Esta obra está sob licença Creative Commons. 


\section{A contestação do padrão masculino da linguagem e a poesia de Maria Teresa Horta}

É um fato amplamente aceito e reconhecido que a linguagem é a principal característica que difere os seres humanos dos animais. Questionamos, porém: que linguagem é essa? Ela serve para todos os seres humanos? As regras da linguagem - tanto a dos manuais, quanto a das cenas cotidianas - e da sociedade impõem-nos o masculino como padrão; logo, ao nos referirmos a alguém, é preceito extensivamente aceito usar a palavra "homem" para designar os seres humanos, independentemente de seu gênero.

Esse é um exemplo, de cunho onomástico, de um preconceito epistemológico que nos assombra: o homem, como representante do sexo masculino, torna-se a medida de todas as coisas: um padrão ou norma a partir da qual a humanidade é reconhecida. Mas onde entra a mulher nesse jogo social da mesmidade?' A mulher, nessa lógica, é tradicionalmente a não homem, ou não toda, entendida por meio da sua relação de falta com a "figura central": falta-lhe o pênis, metonímia do falo.

Contudo, essa lógica não é a única e não compreende o ser mulher. Por isso, podemos olhar para a questão da mulher através de um outro sistema de significação, o da diferença sexual a partir do viés do pensamento feminista francês, que propõe uma leitura diversa daquela fundada pelo patriarcado. Neste, a mulher é reconhecida como mulher e não como não homem. Parte-se, então, do pressuposto de que não existe uma relação fixa de hierarquia entre um sexo e outro, justificada pela lógica da mesmidade. A mulher é entendida por si só, sem se associar à figura masculina ou ao homem. Assim como o homem é homem, a mulher é mulher, o que nos traz uma possibilidade social de horizontalidade do poder que se relaciona à definição de gênero. ${ }^{2}$ Então, se a mulher e o homem são dois sexos/ gêneros diferentes, sem relações de similaridade que pressuponham um ser à imagem do outro, a linguagem que os difere dos animais não precisa ser, e não é, única e universal. Ela se comporta em múltiplas facetas, assim como as possibilidades dos femininos e dos masculinos, marcadas também por diferentes experiências no mundo.

A linguagem, segundo Roland BARTHES (1994), é a manifestação do poder. É ela que nos obriga a fazer escolhas para que possamos nos comunicar. Para manifestarmonos, é preciso fazê-lo por meio da exclusão de algumas possibilidades da língua em benefício de outras, não nos restando outras palavras além daquelas que nos são impostas pelo sistema. Existem, em cada língua, uma ordem sintática e um inventário lexical que se estabelecem e que precisam ser seguidos; do contrário, não há comunicação. Tais ditames da língua mantêm a hierarquia do poder, pois ela é o próprio poder. Por isso, quando uma linguagem exclui de si as possibilidades de uma imanência feminina, tendo como seu "neutro", seu "padrão" e "universal" o masculino, ela é duplamente opressora: ao mesmo tempo em que obriga a dizer de acordo com os seus códigos de linguagem, exclui a mulher. É, pois, indispensável recuperarmos uma linguagem que existe e que integra o

\footnotetext{
'A mesmidade é a lógica na qual o homem é o padrão, então a mulher e todos os outros seres humanos que não se enquadram no binarismo sexual - homem/mulher, masculino/feminino -, são sempre definidos a partir dele, seja por aproximação ou distanciamento. A partir dessa definição do homem como figura central, justifica-se a posição hierárquica superior que ele tem em relação à mulher, o que torna esse sistema de significação essencialmente opressor e patriarcal.

${ }^{2}$ Podemos ressaltar (talvez de uma forma otimista para a realidade na qual nos encontramos, mas com fortes desejos de que essa realização seja uma possibilidade mais equânime para os seres humanos) que, uma vez que se admite que há uma relação de poder pautada na horizontalidade das relações de gênero, é possível que as relações de poder aos poucos possam ser apagadas no que concerne também às pessoas que não se definem a partir dessas relações.
}

2 Revista Estudos Feministas, Florianópolis, 26(2): e44115 
feminino, uma linguagem que conceba a mulher como inteira e completa e que parta desse corpo feminino que é em si.

Na procura por uma linguagem que abarque a mulher, encontramos Maria Teresa Horta, escritora portuguesa que se fala mulher por meio de sua lírica. Nascida em um Portugal às vésperas de uma longa e rigorosa ditadura, a poetisa viveu seus anos de juventude durante o Estado Novo Português; portanto, desde cedo teve seus direitos cerceados por um governo que previa e impunha as condições nas quais as mulheres deveriam viver. Recatada dentro do lar e manifestando-se apenas para declarar o amor pelo lar e pela pátria, a mulher portuguesa não poderia se descobrir enquanto mulher de outra forma que não a imposta pelo governo.

Maria Teresa Horta recusou-se a ser a mulher modelo portuguesa e desde cedo enfrentou um Estado machista ao se colocar como jornalista no mundo do trabalho - ainda que isto the acarretasse maior percepção de sua exclusão social por precisar trabalhar em espaço separado na redação, pois supostamente os homens não conseguiriam ser espontâneos trabalhando em presença de uma mulher (Maria João FAUSTINO, 2014) - e da cultura ao escrever poesia erótica, sendo, por esse motivo, perseguida pelo Estado português e alguns de seus mais respeitados cidadãos. Mas a poetisa não se deixou silenciar, ainda que viesse a responder a processo judicial pela publicação de seu livro junto a Maria Isabel Barreno e Maria Velho da Costa; continuou, pois, a escrever poesia e trabalhar como jornalista, atuando, dessa forma, não apenas em seu próprio benefício, mas em prol da mulher em sua liberdade profissional e cultural.

\section{A construção do ser mulher e suas manifestações na e pela linguagem para chegar à escrita feminina}

Na perspectiva da diferença sexual, Luce IRIGARAY (1997), feminista e filósofa belga, apresenta-nos o falar (como) mulher. ${ }^{3}$ Segundo a autora, a mulher tem a sua entrada na ordem do simbólico de uma forma completamente diferente da que é tomada como padrão para homens (e não homens) pela psicanálise tradicional. Para a autora, a mulher não estabelece uma relação de ausência com o objeto (mãe) por meio de mecanismos como o do fort-da, de Sigmund FREUD (1996), uma vez que ela e a mãe, ao compartilharem o corpo feminino, não se relacionam por intermédio da ausência, da fenda, mas, sim, segundo uma relação de presença.

Dessa discussão advém a metáfora de Irigaray para os lábios que se tocam mutuamente. As mulheres possuem lábios (vaginais e bucais) que se tocam, o que faz com que o falo não lhes faça sentido ou falta. Ou seja, para o seu gozo, não é necessária uma intervenção que advenha de fora do corpo; é a própria presença que faz a mulher gozar (e, como mencionado acima, relacionar-se com o simbólico). Dessa forma, a filósofa enaltece as múltiplas possibilidades de prazer feminino, o que se diferencia da centralidade de prazer masculino. Construindo sua metáfora, Irigaray discorre sobre as diferenças que existem entre os corpos e que se manifestam não apenas na entrada do simbólico, na linguagem e no corpo, mas também em todas as relações da mulher com o mundo. A autora enaltece as potencialidades de um corpo feminino que se reconhece como de mulher e que não se prende a padrões.

As mulheres, portanto, desde a tenra idade, relacionam-se com o mundo de uma forma diferente da dos homens, pois possuem uma linguagem diferenciada da tomada como padrão, especialmente a partir da sua socialização enquanto mulheres. Essa

\footnotetext{
${ }^{3}$ No original, parler femme.
} 
linguagem se manifesta por meio do falar (como) mulher (IRIGARAY, 1985) e se relaciona com seu próprio corpo: é dele que a linguagem das mulheres flui para fazer sentido.

Segundo a autora, embora as mulheres usem essa linguagem para falarem entre si, não é a todo o momento que isso é possível. O falar (como) mulher só acontece quando as mulheres estão entre mulheres e não são atravessadas pelo logocentrismo. É, portanto, necessário que elas se livrem das amarras patriarcais para que possam se expressar de acordo com o que lhes é próprio. O ato de falar (como) mulher se torna uma ação revolucionária. Libertar-se dos grilhões linguísticos e culturais impostos às mulheres é importante para que estas possam se manifestar integralmente e de forma ampla.

Mas, para tal inserção na materialidade do mundo, é necessário caminhar mais à frente na revolução dessa linguagem, para que haja, de fato, um empoderamento feminino. É fundamental que esse falar (como) mulher se transforme em outras manifestações semióticas, como a escrita, a pintura, a escultura, a performance, o teatro, a política, a educação, a economia. Como parte dessa agenda político-crítica, o presente artigo detém-se na questão da escrita; essencialmente, na escrita feminina.

Para entender a perspectiva que ora se apresenta sobre uma escrita feminina, é preciso levar em conta alguns encontros conceituais que agora serão apresentados. $O$ termo écriture féminine ${ }^{4}$ foi cunhado por Hélène Cixous no ano de 1975, conclamando as mulheres a se liberarem de uma mentalidade masculina e a entrarem em contato com um inconsciente feminino ligado de forma intensa à potência erótica e sexual de seu corpo. Assim como Irigaray, Hélène CIXOUS (2007 [1975]) enaltece a multiplicidade da mulher e de seu prazer ao evidenciar que não se pode falar de uma sexualidade feminina que seja "uniforme, homogênea, classificada por códigos" (p. 319 [tradução nossa]), de maneira análoga à de Julia KRISTEVA (1984), quando esta relaciona o feminino à linguagem semiótica enquanto movimento constante anterior à nomeação.

Dessa forma, Cixous deseja que todas as mulheres possam falar de sua sexualidade - que é tão plural -, de forma a colaborar com o empoderamento de outras mulheres e possibilitar a percepção de que elas também transbordam sua sexualidade (para além do único local de prazer). Mas, mais que isso: para que as mulheres não se envergonhem de extravasar seus desejos e não tenham que se prender dentro da lógica da localização única do prazer.

O caminho da escrita feminina, segundo Cixous (2007 [1975]), é também um caminho de empoderamento do próprio corpo feminino, pois escrita feminina e corpo se misturam e se tornam um só quando a primeira é a manifestação como rastro (Jacques DERRIDA, 2013) do segundo. O percurso de retomada do corpo e da escrita se faz necessário uma vez que, junto aos corpos femininos, a escrita feminina foi trancafiada no espaço do privado aquele de dentro de casa, do claustro religioso, do corpo imaculado e das portas fechadas. Uma mulher enclausurada mantinha sua escrita presa até mesmo para si, como um segredo obscuro e pecaminoso. Gozar o corpo e fruir a escrita faziam parte dos interditos aos quais as mulheres eram submetidas: recuperar corpos e escrita se faz necessário.

\section{Uma leitura feminista da lírica de Maria Teresa Horta}

Na medida em que a mulher escreve e descobre o seu próprio corpo, ela vai se libertando das proibições que lhe foram impostas. Escrita e corpo são uma coisa só e ambos se revelam nesse processo, pois não há estaticidade no corpo; este se modifica a cada novo toque, assim como a escrita feminina acontece só como processo e não pode ser apreendida como objeto fechado.

${ }^{4}$ Aqui o termo será traduzido como "escrita feminina". 
Para falar de mulher, tomamos como ponto de partida a obra lírica de Maria Teresa Horta, poetisa portuguesa e figura importantíssima no que concerne ao empoderamento feminino no mundo da literatura. Desde a sua entrada no mundo do trabalho, Maria Teresa desafiou a sociedade patriarcal: foi uma das primeiras mulheres a fazer parte de um cineclube português e na sua carreira de jornalista precisou, por ser mulher, escrever em uma sala apartada na redação em que trabalhava.

Seu primeiro livro de poesia publicado foi Espelho Inicial, no ano de 1960. Seguiramse a este outras obras importantes que traziam à tona a poesia de uma eu-lírica ${ }^{5}$ dona de seu próprio corpo e que o expressa por meio de uma escrita feminina. O erotismo é um dos temas principais que percorre os poemas dessa escritora, e aqui é importante notar que esse erotismo é a fruição do corpo feminino que questiona, inclusive, a forma como é concebido pela sociedade patriarcal.

Além de seus livros de poesia, Maria Teresa Horta também escreveu em prosa, nomeadamente a obra As Luzes de Leonor (2011), com a qual foi galardoada com o prêmio D. Dinis, em 2011 . Outra obra importante da autora, tanto por sua repercussão política quanto pela maestria literária, em que desafia os padrões literários vigentes, é Novas Cartas Portuguesas (1972), escrita em coautoria com Maria Velho da Costa e Maria Isabel Barreno. A obra das Três Marias foi apreendida pelo governo de Marcelo Caetano, e as autoras foram autuadas pelo poder público, sendo presas e tendo que responder a um processo judicial por um livro que supostamente atentava contra os princípios portugueses da moral e bons costumes. A intervenção de feministas do mundo para a suspensão do processo judicial fez com que esse fosse o primeiro caso feminista de repercussão internacional.

Ao mesmo tempo em que Maria Teresa Horta se coloca no espaço público de forma a confrontar a sociedade patriarcal - seja num momento em que o estado fascista português, - Estado Novo, está no poder, ou quando se posiciona politicamente ao se recusar a receber o prêmio $D$. Dinis das mãos do então primeiro ministro português, por não concordar com suas posturas políticas -, a poetisa mantém em sua obra uma atitude irreverente e libertária que dá voz às mulheres que não se ajustam aos padrões que a sociedade falogocêntrica lhes impõe, trazendo à tona uma escrita do corpo que não se cala e não aceita as amarras impostas pelo patriarcado. É através da escrita feminina, escrita do corpo de mulher, que não obedece mais aos interditos impostos pelo falogocentrismo, que Maria Teresa Horta dá voz à eu-lírica de seus poemas como ato de poesia, de amor e de libertação feminina.

O ato de se entregar à poesia com o corpo, ou do corpo escrever-se como poesia, pode ser encontrado no poema "Fazer amor com a poesia", inserido na seção "Inéditos" do livro As palavras do corpo: antologia de poesia erótica (2012), em que a eu-lírica faz da poesia amante do corpo.

\section{FAZER AMOR COM A POESIA}

Deito-me com as palavras beijo a boca dos poemas quando a razão desvaria

\footnotetext{
${ }^{5}$ Nesta primeira ocorrência dentro do corpo do texto, gostaríamos de marcar que, ao longo do trabalho, a instância lírica do poema será chamada de eu-lírica, em ato político contra o apagamento do sujeito feminino no texto poético.
} 
Manipulo a linguagem

Tomo a nudez dos meus versos

Faço amor com a poesia (Maria Teresa HORTA, 2012, p. 291).

Neste poema, observamos a cumplicidade que existe entre a eu-lírica e a linguagem que forja a partir de seu corpo. A aproximação sintática dos termos do paradoxo existente na oração "quando a razão desvaria" nos faz pensar na apropriação de uma nova linguagem quando a ordem estabelecida é quebrada, ou seja, quando a razão - que emana da lei do falo, do logos, e, por conseguinte, representa a sociedade apolínea e patriarcal - deixa de fazer sentido, entra num colapso e se torna louca - já não significando para a mulher. Nessa invectiva linguística contra a lógica da metafísica e de todo binarismo, as palavras que vêm da imanência do corpo ("beijo a boca dos poemas") aparecem e se materializam em um corpo que se derrama em prazer.

No poema, essa linguagem é manipulada (termo significativamente ambíguo entre o erotismo e a trapaça, que Barthes (1994) bem dissera ser o regime do literário) e transformada em nova palavra através da relação de corpo que se estabelece entre eu-lírica e linguagem. Na personificação da poesia, há a fusão entre corpo poético e o corpo da eu-lírica, numa apropriação do verso desnudado, o que se replica, enquanto estrutura poética, para a hibridação entre o título do poema e seu último verso: a semelhança do corpo dessas orações, em suas escolhas lexicais, só significa na diferença do gesto, ou da flexão verbal - infinitivo e $1^{a}$ pessoa do singular, em que a mensagem e o enunciador devêm um.

Assim, quando há a quebra simbólica com o logos e com a sociedade que é por ele manipulada, ou construída, a mulher consegue transcender e agir numa nova ordem simbólica e social, trazendo para si, como no último verso, o lema expresso no título. Ainda que vista como a desvairada - porque, ao extrapolar a Lei, ela só pode ser vista sob um olhar ostracista -, há a possibilidade de uma nova leitura de mundo, de si e do ato poético.

O ato de sua escrita como imanência do corpo pode ainda ser relacionado com a recuperação de sua potência erótica. Essa eroticidade, segundo Audre LORDE (1984), está presente em todos os aspectos da vida humana e negá-la é perder a capacidade de ser inteira como mulher. Quando uma imposição sobre o corpo é prescrita por outrem (no caso, o falogocentrismo que reprime corpo e escrita), não há mais possibilidade de gozo erótico, mas de um abuso pornográfico - ter o desejo usado por outra pessoa - por parte de uma sociedade pautada no abismo do falo. Recuperar a escrita é recuperar o corpo e, por conseguinte, ter de volta a própria potência erótica e poder gozar em si e por si. Corpo que se quer corpo, escrita que vaza esse corpo. A escrita feminina, segundo Cixous (2007), ao recuperar o corpo, torna-se política, uma vez que a mulher se apropria de seu próprio discurso.

Dessa forma, podemos ver o encontro entre o falar (como) mulher e a escrita feminina se tornar um belo abraço quando compreendido nas palavras de Cixous (2007):

É pela escrita, de e para mulheres, e por aceitar o desafio do discurso que tem sido governado pelo falo, que as mulheres vão confirmar as mulheres em um outro local que não é o que lhes foi reservado no e pelo simbólico, isto é, em um outro local que não o do silêncio. Mulheres deveriam romper com a armadilha do silêncio. Elas não deveriam ser iludidas a aceitar o domínio que é a margem do harém (p. 324 [tradução nossa]).

Assim como Irigaray nos alertou da impossibilidade de delinear (delimitar, excluir novas possibilidades, limitar) o que é ser mulher e o falar (como) mulher, Cixous nos revela que definir uma escrita feminina não é possível, pois esta ultrapassa o discurso que regula o falocentrismo; logo, é indefinível segundo sua lógica de definições, oposições e 
significações estanques. Ela só é figurada quando o automatismo desse sistema é ultrapassado. Escrever fora do padrão imposto pela linguagem é entendido aqui como uma escolha (lexical, sintática, política): deixam-se de lado algumas possibilidades de linguagem para usar outras, e nesta escolha há uma implicação ético-estética.

A escrita feminina se aproxima ainda da definição da linguagem poética de Kristeva, dado que ambas não estão contidas dentro da linguagem cotidiana (KRISTEVA, 1984); não podem, portanto, ser definidas e delimitadas. A escrita feminina não é englobada dentro da linguagem em si - dessa linguagem fascista que dita a regra falogocêntrica do ser; há nela algo que ultrapassa as margens da linguagem, visto que não pode ser concebida como um produto, mas sim como um processo. É o constante fluir da economia dos líquidos (IRIGARAY, 1985) que está presente na linguagem feminina, unindo o falar (como) mulher e a escrita feminina, entre outras inúmeras possibilidades da produção semiótica feminina. A construção do corpo da mulher por si mesma está expressa em sua linguagem.

Desse modo, o interdito deixa de ser local apenas de negação da escrita feminina para se transformar em lócus de legitimação de uma nova prática. A partir da existência de uma linguagem feminina como interdito, o movimento de ultrapassá-lo é legitimado, fazendo com que a linguagem feminina possa ser observada dentro de sua positividade. A linguagem poética, como definida por Kristeva (1984, p. 114), faz do proibido o único sistema em que a contradição não é contrassenso, de forma a permitir que novos conjuntos vazios se tornem "um modo de encadeamento particularmente significante". A escrita feminina se legitima ao ultrapassar o fascismo do sistema falogocêntrico.

Assim, escrita feminina e falar (como) mulher se aproximam, criando um elo importante dentro da diferença sexual através da linguagem feminina: a mulher fala de si e para si, fala com outras mulheres numa linguagem sua e que não é compreensível para o homem, pois está fora da linguagem - é a "não toda" - e fala com o corpo. Suas palavras são "balbucios" e, nesse sentido, se aproximam da fala da criança, para quem o som e a sua articulação com o corpo têm um significado que vai além da linguagem oral (Lúcia Castelo BRANCO; Ruth Silviano BRANDÃO, 2004).

Tal aproximação entre falar (como) mulher e a linguagem da criança não coloca as mulheres num patamar de infantilização; pelo contrário, demonstra que a sua linguagem não segue a ordem estabelecida pelo falogocentrismo, que é regida pela lei externa ao próprio corpo. Em vez disso, trata-se de uma cadeia significante que passa pelas sensações corporais para se fazer fala. Sua fala faz parte de uma linguagem pré-verbal, e essa reaproximação com o caráter originário da fala e da língua, em que palavras recobram a corporeidade da enunciação, sublinha o estatuto poético da escrita feminina.

Essa fala pré-verbal é corporal na medida em que é a fala do próprio corpo que se frui, escapando da lógica exterior que o falogocentrismo impõe à linguagem. A transferência que se faz da fala para a escrita - fala do corpo que se torna escrita do corpo - ressignifica a linguagem ao levar a palavra para um outro lugar de significação, que não o dominado por um corpo preso no logos falocêntrico. O corpo toma, dessa forma, outra dimensão: "é no momento em que a linguagem verbal se cala que o corpo da personagem invade a cena, por meio da tentativa exaustiva da narradora de reconstituí-lo, de restaurá-lo" (BRANCO; BRANDÃO, 2004, p. 153). Nessa citação, quando substituímos a voz "narradora" por voz lírica, passando da prosa à poesia, entendemos como Maria Teresa Horta se torna todas as mulheres ao dar voz a uma mulher que não é compreendida dentro do verbal. O que temos é a experiência feminina que não cabe na palavra e, por isso, transcendê-la é unir as mulheres em uma, sem, com isso, delimitá-las, fechá-las, dar-lhes um sentido único. 
Nesse contexto, vale levantar a discussão de Juliana Batista de OLIVEIRA (2006) sobre a questão da coletividade na poesia de Maria Teresa Horta:

Quando Horta escreve, ela não descreve apenas a sua relação individual com o mundo. Ela sempre estará espelhando aqueles que, assim como ela, sofrem o seu mesmo tempo mítico, o tempo da cultura entranhado na memória dos corpos (p. 30).

Nota-se aí que a relação dessa mulher com as outras mulheres se dá não só em termos de vivências culturais e econômicas, mas também no âmbito da linguagem que se constitui como rastro. É o traço que se refaz, assim como corpo que se modifica a cada novo ciclo. Corpos que se fazem e refazem em discurso e que constituem novos rastros a cada instante. A eu-lírica se amplia ao entoar a possibilidade de outras vozes femininas, rompendo barreiras e construindo caminhos para a presença da escrita feminina.

É nesse movimento que entendemos que a escrita feminina não tem a intenção de comunicar; ela demanda "ser". Ou seja, não existe um pensamento a ser decifrado ou compreendido; ela não noticia, ela é. Dessa forma, a poética de Maria Teresa Horta se erige sendo, e não representando. A mulher se faz através de uma eu-lírica que não se prende dentro de um discurso sólido dominado pela linguagem fálica. É nos intervalos que ela pode ser completa.

O que dizer, então, de um texto que se erige a partir dessa inexistência, desse nada, e que no entanto insiste, em sua própria materialidade, em afirmar: aqui estou eu, um texto outro, falando numa outra dicção, talvez de algo que não sei, mas que está aí, na espuma espessa do significante, na voz, no tom, na respiração, no ritmo, nas lacunas, nos excessos, aqui, ali e em nenhum lugar? (BRANCO; BRANDÃO, 2004, p. 147).

O vazio, a lacuna, o abismo, a inexistência da mulher não podem ser encontradas na lógica binária do logos; há aqui uma lógica que ultrapassa o binarismo e o incorpora. A mulher como texto deve ser lida dentro de um paragrama (KRISTEVA, 1984), haja vista que contém a lógica binária em si para ultrapassá-la. A linearidade do logos e do falo é apenas uma parte de sua constituição; é, aliás, a parte que a faz consciente do que precisa sobrepujar para, enfim, dominar o seu próprio discurso. São as linhas traçadas por outros vértices, outros corpos como textos que farão da lacuna da escrita feminina a presença do significado do vazio, e não o vazio como ausência de corpo/texto/palavra.

Sendo assim, não há contornos e limites: o ser mulher transborda as fronteiras estipuladas pelo falogocentrismo e por isso sua escrita se torna subversiva. Ela usa as ferramentas masculinas e de dentro destas faz com que suas bordas sejam alargadas, remodeladas e isso tudo para transcendê-las. A mulher múltipla não teme o abismo que o falocentrismo lhe atribuiu por se saber transbordante.

Nós somos tempestuosas, e isto que é nosso se liberta de nós sem nosso temor de alguma debilidade. Nossos olhares, nossos sorrisos são gastos; risadas exsudam de nossas bocas; nosso sangue flui e nós nos estendemos sem jamais alcançar um fim; nós nunca seguramos nossos pensamentos, nossos signos, nossa escrita; e nós não temos medo da falta (CIXOUS, 2007, p. 322 [tradução nossa]).

Dessa forma, a mulher fala e sua tagarelice e sua risada incomodam por não serem compreensíveis dentro da linguagem do logos. Despertar o olhar apurado e o ouvido atento é necessário para sentir essa outra forma de ser. Ana Maria VICENTINI (1989) relembra que, dentro da lógica estruturada do patriarcado, a mulher foi relegada à posição marginal, submissa e hierarquicamente inferior, de forma que ela não ameaçasse a supremacia do princípio masculino. Ora, a escrita feminina coloca em xeque essa supremacia, mas não o faz na tentativa de "tomar o lugar" do homem na sociedade, e sim de transformá-la para

8 Revista Estudos Feministas, Florianópolis, 26(2): e 44115 
que homens e mulheres tenham lugares diferentes e ocupem espaços horizontais, de forma a não haver supremacia e, sim, equilíbrio. Ultrapassar uma lógica não é, necessariamente, repeti-la ao inverso. Ser mulher e ser homem não se excluem, tampouco se complementam. A eles cabe sua própria linguagem: "Eu escrevo mulher: mulher deve escrever mulher, e homem, homem" (CIXOUS, 1975, p. 321 [tradução nossa]). Escrevendo-se mulher, reconhecendo o seu corpo e o seu lugar de enunciação, a eu-lírica do poema "Paixão", do livro Inquietude (2006), dá voz aos seus excessos e infinidades do sentir.

\author{
PAIXÃO \\ Com a paixão faço \\ e armo \\ a construir-me no excesso \\ Apunhalo o coração \\ enveneno o peito \\ aberto \\ A paixão é meu \\ destino \\ meu final e meu começo \\ Morrer de amor \\ e de amar \\ é a morte que eu mereço (HORTA, 2012, p. 270).
}

O excesso da mulher está localizado nas suas zonas erógenas. É na sua multiplicidade que a mulher acontece: na sua vasta geografia do prazer, na sua múltipla forma de amar, na sua forma de não se conter. E é por isso que a morte é a sua última instância da contingência - quando morre a mulher, já não precisa habitar um corpo limite ("Morrer de amor/e de amar/é a morte que eu mereço"). O desejo da mulher nasce no corpo e o transcende através dos sentidos. A esse respeito, Georges BATAILLE (1987) discorre sobre o desejo de continuação e de sua impossibilidade: o ato sexual busca a imortalidade, aquele pequeno momento em que o ser seria continuado na fecundação; mas não, aquela é a morte de si, pois, ao se fundir com o outro, o ser deixa de ser - já é outro.

A eu-lírica, ciente de que é no mundo, opta por usar a primeira pessoa do singular na escrita do poema, deixando claro que fala de uma localização específica, que é a de seu corpo. Ter domínio de si e de seus atos a torna ativa no que o patriarcado lhe daria o papel passivo: inverte-se, assim, o sentido da paixão que dá título ao poema; passio ganha a dimensão de agência sobre si e sobre o mundo.

Nesse sentido, o uso predominante dos verbos no presente do indicativo vai ao encontro da necessidade de paixão da vida da eu-lírica: "A paixão é meu/destino/meu final e meu começo". No verso, os substantivos "final" e "começo" demarcam dois tempos fora do presente, o qual se entende aqui de forma transgressora, retornando a um eterno agora: ato daquele que comparece em seu próprio corpo e contexto, como ser-aí. Assim, sob a pele do "faço", "armo", "apunhalo" e "enveneno", há um "fiz", "armei”, "apunhalei", "envenenei", e um "farei”, "armarei”, "apunhalarei" e "envenenarei”, porque todos esses atos se repetirão ao longo da história, que um dia começou e um dia findará. É o excesso pela repetição: repetição de si, de seus atos, de seu corpo que se transforma. Sempre um novo, ainda que o mesmo. 
A relação com o próprio corpo se torna essencial no 'constituir-se' mulher. Adrienne RICH (2007 [1984]) nos lembra que não é apenas a relação com o corpo, pois esse corpo pode ser qualquer um; é o conhecimento do próprio corpo que se faz necessário - do meu corpo eu posso falar com autoridade. Não é uma necessidade de transcendência do corpo, mas de reivindicá-lo. Ao reclamar seu próprio corpo, libertá-lo da vigilância patriarcal, a mulher se empodera de si, e do movimento de uma nasce a possibilidade de as outras se moverem. O corpo se torna coletivo na medida em que as marcas do feminino são exigidas e construídas pelas mulheres e saem das mãos do homem.

Observamos na lírica de Maria Teresa Horta uma confluência entre os desejos do próprio corpo e o amor por ele próprio. Segundo Miriam Raquel Morgante BITTENCOURT (2005), os poemas da autora "mostram que o erotismo jamais se desvincula do sentimento amoroso. Há uma relação íntima entre amor e sexualidade em todos os poemas" (p. 77), fazendo com que a sua poesia seja "declaradamente instrumento da luta revolucionária" (p. 77) que traz para o local da agência o corpo e os seus desejos, dando voz ao corpo feminino através da escrita de si.

Hélène Cixous (1991) enobrece os sentimentos do corpo, transformando-os em escrita: as palavras, por si próprias, aquelas que ainda estão na movência pré-tética (KRISTEVA, 1984), sem nomes definidos dentro de leis exteriores, transformam-se em bolhas de luz que se volatizam pelo corpo - com uma imensa necessidade de se fixar no ventre. No poema "Propósito", presente no livro Inéditos (2012), a eu-lírica vai dialogar com esse corpo, já não desconhecido, na trama do escrever poético.

\author{
PROPÓSITO \\ O desejo revolvido \\ A chama arrebatada \\ O prazer entreaberto \\ O delírio da palavra \\ Dou voz liberta aos sentidos \\ Tiro vendas, ponho o grito \\ Escrevo o corpo, mostro o gosto \\ Dou a ver o infinito (HORTA, 2012, p. 289).
}

A primeira estrofe do poema é realizada por meio de frases nominais em contraste com a segunda, em que aparecem orações completas. As frases nominais nos remetem aos sentimentos da eu-lírica e à sua descoberta anterior do corpo - a ausência de verbos nos dá a sensação de que ela lida com algo já ocorrido. O corpo no momento da escrita já lhe é familiar, a voz que urgia dos recônditos desconhecidos de si, remetendo às demandas do corpo (CIXOUS, 1991), aparece aqui em desejos revolvidos, antes examinados, o que torna possível à eu-lírica o aprimoramento do seu conhecimento interior. Os adjetivos "revolvido", "arrebatada" e "entreaberto" são todos formados a partir de uma flexão verbal em particípio, o que nos faz pensar no movimento aprisionado, estagnado: ainda que o adjetivo tenha a força de modificar o nome, ele é estático; a ação perde sua força e se estanca como adjetivo a fim de dar maior força ao substantivo ao qual acompanha.

Vale ressaltar ainda que os substantivos dessa primeira estrofe estão dentro do campo semântico da ardência sexual, elaborando um primeiro momento de contato que vem por meio do desejo, da chama como metáfora da paixão ardente (e que aqui está arrebatada, é violenta e ao mesmo tempo cativa), do prazer que não se conclui e está aberto a novas 
possibilidades através do delírio. Note-se também que o delírio é o único substantivo dessa estrofe que não tem um adjetivo conectado diretamente a si, precisando de um apoio prepositivo: a palavra domina o delírio, realiza-o. O delírio das possibilidades do prazer se expressa por intermédio da palavra e é esta que carrega em si a possibilidade do gozo. Palavra revolvida, ardente e sempre com uma nova possibilidade, como o gozo, que nunca é satisfeito.

A segunda estrofe expressa o movimento vigente, pois os verbos se encontram no presente do indicativo. Ainda que o sujeito não se encontre expresso, chegamos a ele por meio da flexão verbal. Aqui, a eu-lírica é sujeito oculto e ativo; nada acontece de fora para dentro, pois os verbos "dar", "tirar", "pôr", "escrever" e "mostrar" dependem da dinâmica interior. É o desejo da carne que prevalece e que movimenta. A urgência da escrita promove o conhecimento de si, e com a impetuosidade do corpo os sentidos são liberados, tendo as vendas retiradas, de modo que o corpo pode, enfim, dizer-se. Dizendo-se, o corpo é ilimitado, não se contorna por margens. Se a linguagem poética representa uma infinidade do código (KRISTEVA, 2005), a poesia do corpo transcende a linguagem poética e a própria materialidade corporal: não há a localidade do fim.

O poema se expressa em parataxe porque a mulher não se articula; ela transcorre. Não há necessidade de conjunções de coordenação nem de subordinação. Não há pausa; há o constante fluir do ser. "Mulher não para na mulher, não para, flui, escreve-se em parataxe da luz líquida" (CIXOUS, 1991, p. 167 [tradução nossa]). Eis o Propósito do poema: o conhecer-se no fluir sem margens, no interesse e na descoberta do corpo pela voz que emerge das regiões inexplicáveis da interioridade feminina. E elaboramos o propósito da escrita feminina: dar voz ao corpo feminino que foi mantido refém durante muitos séculos das leis do falogocentrismo, e que aos poucos se empodera de si, transformando, além do espaço social e econômico, o ambiente da cultura e das artes.

\section{Considerações finais}

Embora hoje caminhemos em uma sociedade em que as discussões acerca dos direitos das mulheres (à vida, à cultura, à economia, ao corpo, à justiça) vêm crescendo e se afirmando enquanto possibilidade de mudança social no estatuto da mulher, ainda há muito que fazer também no que concerne à produção artística feminina dentro de uma lógica que lhe faça sentido e que não seja expressão de uma mulher vista como "não homem". Dessa necessidade crescente de que haja um lugar das mulheres que lhes pertença em si, pelo que são, e não pelo espelho masculino no qual se apresentam segundo alguns sistemas de significação, as discussões do feminismo da diferença sexual se tornaram importantes para a transformação das mulheres e, a partir dessa reforma, para as mudanças sociais que ela implica. Contudo, o percurso de transfiguração e reforma social é longo, e se faz necessário que mais estudos sobre o sistema da diferença sexual - pelo viés feminista que questiona as formas pelas quais esse sistema foi construído pelo patriarcado, bem como suas falhas - possam ser realizados para o empoderamento feminino.

Nessa perspectiva, entrevê-se o caminhar de uma teoria que ressignifica o corpo feminino por intermédio das metáforas dos lábios para inserir as mulheres em uma ordem simbólica que Ihes é própria (IRIGARAY, 1985), passando por uma linguagem feminina que se entende em seu momento de movência e pré-nomeação (KRISTEVA, 1984), até chegar na materialização dessa revolução da linguagem na inscrição corporal da escrita feminina (CIXOUS, 1991). A escrita feminina é uma arma revolucionária que recupera o corpo da mulher dos grilhões que lhe foram impostos por uma sociedade pautada no falo. Recuperar o corpo é recuperar a mulher. 
Portanto, é desse corpo feminino que a necessidade de escrita aparece (CIXOUS, 1991). E ela surge como uma forma de responder às perguntas que surgem dentro do próprio ser a fim de expandir as possibilidades da mulher (sim, mulher, porque esta não está se pronunciando acerca da experiência do corpo alheio, e sim do semelhante) e não a restringir ao seu local, sua cultura, sua família. O corpo demanda essa escrita, é a própria carne que grita e enlouquece a mente no afã de libertá-los, como numa linguagem que habita o corpo e que finalmente encontra a sua possibilidade de atingir o mundo. Reclama-se o próprio corpo quando a escrita é corporal. Mas qual o direito que a mulher possui de escrever? Não importa, ela deve escrever! "O ataque [do corpo] era imperioso: 'Escreva!'” (CIXOUS, 1991, p. 9 [tradução nossa]). E é por falarmos de corpo que a indagação não pode ser esquecida: quando foi que as mulheres tiveram direito aos seus próprios corpos? Será que hoje temos? É preciso tomar o corpo e ressignificá-lo com a sua própria escrita para que haja liberdade. Que se tome o corpo como numa guerra, ato revolucionário e de sobrevivência. Pois hoje o corpo é que faz a demanda quando a mente diz, repetidamente, que não se é capaz, que não se tem o poder, que não se tem o direito. O corpo impele a mulher a se libertar da prisão que lhe foi imposta. A Lei do Pai não está a seu favor... mas o seu corpo é impetuoso:

É uma força que te faz cruzar oceanos. Eu, escrever? Mas eu não era um profeta. Uma ânsia se bateu no meu corpo, mudou meus ritmos, sacudiu enlouquecidamente meu peito, tornou o tempo não vivível para mim. Eu era tempestuosa. "Queime!". "Você deve falar!". Além do mais, que voz é essa? O desejo tinha a violência de um trovão. [...] Uma jubilosa força. Não um Deus; ela não vinha de cima. Mas de uma região inacreditável, dentro de mim, mas incognoscível, como se pudesse existir algum lugar no meu corpo (o qual, de fora, e do ponto de vista naturalista, é extremamente elástico, nervoso, vívido, delgado, não sem charme, músculos firmes, um nariz pontudo sempre tremendo e úmido, patas vibrantes) outro espaço, sem limites; e lá, nessas zonas que me habitam e nas quais eu não sei como viver, eu as sinto, eu não as vivo, elas vivem em mim, jorrando das fontes das minhas almas, eu não as vejo mas as sinto, isto é incompreensível, mas é como é (CIXOUS, 1991, p. 9-10 [tradução nossa]).

Essa violência do corpo é a própria violência da escrita que emerge de lugares antes não conhecidos. É necessário ouvir o corpo! É necessário transbordá-lo em escrita. Ela é tão intensa que a própria palavra crítica da autora (Cixous) se transforma num rio de lavas, poético. Uma imagem depois da outra vai deslizando e se cristalizando em imagens luzentes. Do calor à luz, numa imensidão poética e erótica que prende a leitora num grande suspiro. Da leitura ao corpo, da mansidão ao turbilhão que desperta e que também diz: escreva! Você pode e você deve! O que é seu as normas e as formas não tomarão! Seu corpo, suas leis, suas palavras.

Maria Teresa Horta respondeu a esse chamado do corpo. Seu ato revolucionário e de sobrevivência se dá em sua potência de dar voz a uma eu-lírica que fala numa escrita feminina que emana do corpo. Ela desafia o poder falogocêntrico da sociedade e da cultura, dando às mulheres, por meio de sua voz, o espaço do público. A eu-lírica da poesia de Maria Teresa Horta goza a linguagem ao subvertê-la. Ela convida-a para a dança e, juntos, escrita, corpo e eu lírica revolucionam as normas e ultrapassam-nas, recriando a linguagem e contradança. Dançam e gozam na revolução da linguagem poetizam o corpo libertando as mulheres, contestando as normas e as regras da linguagem que são a metonímia da sociedade.

\section{Referências}

BARTHES, Roland. Aula. São Paulo: Cultrix, 1994. 
BATAILLE, Georges. O erotismo. Porto Alegre: L\&PM, 1987.

BITTENCOURT, Miriam Raquel Morgante. A escrita feminina e feminista de Maria Teresa Horta. 2005. 189 f. Tese (Doutorado) - Faculdade de Ciências e Letras de Assis, UNESP, Assis.

BRANCO, Lúcia Castelo; BRANDÃO, Ruth Silviano. A mulher escrita. Rio de Janeiro: Lamparina Editora, 2004.

CIXOUS, Hélène. "The Laugh of the Medusa" [1975]. In: FREEDMAN, Estelle B. The essential feminist reader. New York: Modern Library, 2007. p. 318-324.

CIXOUS, Hélène. "Coming to Writing" and Other Essays. Cambridge: Harvard University Press, 1991.

DERRIDA, Jacques. Gramatologia. Tradução de Miriam Chnaiderman e Renato Jaime Ribeiro. São Paulo: Perspectiva, 2013.

FAUSTINO, Maria João. "Maria Teresa Horta Jornalista: percurso, memória e circunstância". Revista Comunicação Pública, v. 9, n. 15, p. 1-17, 2014.

FREUD, Sigmund. Obras psicológicas completas de Sigmund Freud. Rio de Janeiro: Imago, 1996.

HORTA, Maria Teresa. As Palavras do Corpo. Lisboa: Publicações Dom Quixote, 2012. (Antologia de Poesia Erótica)

IRIGARAY, Luce. "O Gesto da Psicanálise". In: BRENNAN, Teresa (Org.). Para além do falo: uma crítica a Lacan do ponto de vista da mulher. Rio de Janeiro: Record; Rosa dos Tempos, 1997. p. 171-185.

IRIGARAY, Luce. This sex which is not one. Ithaca: Cornell University Press, 1985.

KRISTEVA, Julia. Introdução à Semanálise. 2.ed. Tradução de Lúcia Helena França Ferraz. São Paulo: Perspectiva, 2005.

KRISTEVA, Julia. Revolution in Poetic Language. New York: Columbia University Press, 1984.

LORDE, Audre. "Uses of the Erotic: The Erotic as Power". In: Sisters Outsider: essays and speeches. New York: The Crossing Press Feminist Series, 1984. p. 53-59.

OLIVEIRA, Juliana Batista de. Tatuagem da Palavra: Educação Sentimental do Corpo no Corpus poético de Maria Teresa Horta. 2006. 151 f. Dissertação (Mestrado) - Universidade Federal do Rio Grande do Norte, UFRN, Natal.

RICH, Adrienne. "Notes toward a Politics of Location" [1984]. In: FREEDMAN, Estelle B. The essential feminist reader. New York: Modern Library, 2007. p. 367-384.

VICENTINI, Ana Maria. "Mudar a referência para pensar a diferença: o estudo dos gêneros na crítica literária". Cadernos de Pesquisa, São Paulo, n. 70, p. 47-52, agosto 1989.

[Recebido em 08/04/2016, reapresentado em $28 / 08 / 2017$ e aprovado em 27/10/2017]

\section{Woman's Writing/Female Writing in Maria Teresa Horta's Poetry}

Abstract: In the search for women's writings that talked about the female body, we found Maria Teresa Horta's poetry. In her poems, the Iyrical-I gives voice to a feminine body so as to untie it from the patriarchal domain. Therefore, there is a feminine voice and writing that derive from a bodily immanence initially manifested inspeech - as in Luce Irigaray's concept of speaking as a woman - and concretized in the writing - as in Hélène Cixous' understanding of female writing. The theoretical path herein taken for the literary analysis of that writing is based on the feminism of difference. For Hélène Cixous and Luce Irigaray, theorists of the feminism of difference, by means of the empowerment of her language a woman subverts phalogocentrism and empowers herself, thus promoting a new possibility of articulating the woman in art and culture. Under such perspective, Horta's poetry becomes libertarian, as it talks about a body what writes itself. Keywords: Female writing; Sexual difference; Maria Teresa Horta 
Natália Salomé de Souza (natsalome@gmail.com) é doutoranda em Estudos Literários pelo Programa de Pós-Graduação em Estudos de Linguagens da Universidade Federal de Mato Grosso. Mestre em Literatura pelo Programa de Pós-Graduação em Estudos de Linguagens da Universidade Federal de Mato Grosso. Licenciada em Letras pela Universidade Federal de Mato Grosso. Trabalha com os seguintes temas: Crítica Literária Feminista, Poesia Moderna e Contemporânea, Semiologia e Pedagogia Waldorf.

Vinícius Carvalho Pereira (viniciuscarpe@gmail.com) é doutor e mestre em Ciência da Literatura pela Universidade Federal do Rio de Janeiro. Bacharel e Licenciado em Letras Português/Inglês pela Universidade Federal do Rio de Janeiro. Professor do Departamento de Letras da Universidade Federal do Mato Grosso e credenciado como docente no Programa de Pós-Graduação em Estudos da Linguagem da UFMT. Atua principalmente nas seguintes áreas: Línguas Estrangeiras Modernas; Literatura Moderna e Contemporânea; Literatura, Mídia e Tecnologia; Semiologia e Tecnologias Digitais na Educação. Atualmente, é coordenador pedagógico de inglês do programa ldioma sem Fronteiras na UFMT.

14 Revista Estudos Feministas, Florianópolis, 26(2): e44115 